\title{
Improving summer and autumn feed quality in New Zealand hill country
}

\author{
G.M. RENNIE' ${ }^{1}$, W.McG. KING ${ }^{1}$, T.L. KNIGHT ${ }^{2}$, B. DEVANTIER ${ }^{3}$ and C.J.HOOGENDOORN ${ }^{3}$ \\ ${ }^{1}$ AgResearch, Ruakura \\ ${ }^{2}$ AgResearch, Lincoln \\ ${ }^{3}$ AgResearch, Grasslands \\ grant.rennie@agresearch.co.nz
}

\begin{abstract}
Management of late spring surpluses to restrict reproductive growth can increase the quality of hillcountry pastures during summer and autumn. This occurs through a reduction in accumulated stem and dead material and an increase in clover content. However, there is little information on the magnitude and longevity of these effects. This trial investigated the effects of four late spring defoliation intensities on herbage quality, measured at the end of spring and during summer. Treatments were applied through regular cutting of hill pastures in areas of medium fertility and slope on two aspects in each of four geo-climatically different hill-farming regions over two years. Pasture herbage quality at the end of spring followed expected trends: defoliation to low residual pasture height led to higher quality herbage. The maximum difference in quality between the lowest cutting height and nil cutting at this time was nearly $2 \mathrm{MJME} / \mathrm{kg} \mathrm{DM}$. With a change to uniform cutting height across all plots in early summer, these pasture quality differences reduced and disappeared.
\end{abstract}

Keywords: Pasture quality, hill country, grazing management

\section{Introduction}

With the ongoing development of much of New Zealand's flat and rolling land into dairying or dairy support, there is increasing pressure on hill country to improve productivity. Ideally, this means trying to grow and finish young stock on country previously used for breeding stock. This demands higher pasture quality than is typical on hill country. Pasture management in mid to late spring has a strong influence on pasture quality in summer and autumn in New Zealand hill country pastures. Manipulation of defoliation frequency and intensity during mid to late spring can impact summer and autumn pasture quality and quantity (Orr et al. 1988). Summer/autumn management is mainly concerned with maintaining herbage quality in summer wet areas and controlling animal pressure in summer dry areas for drought management and winter feed stocks (Clark 1994). Deferred grazing to effectively transfer pasture from late spring into summer and autumn is difficult due to detrimental effects on pasture quality, plant density and species composition (Sheath et al. 1987). Various grazing management guidelines have been published to inform hill farmers of pasture management considerations during this period (Sheath \& Bircham 1983; Sheath et al. 1987; Smith \& Dawson 1977). The effect of defoliation intensity and frequency on summer and autumn net herbage accumulation has been well studied (Sheath \& Boom 1985; Orr et al. 1988), as well as the animal production costs of carrying out these defoliation strategies (Smeaton et al. 1984).

It has previously been shown that management of late spring surpluses to restrict/remove reproductive growth will increase summer pasture quality through a reduction in accumulated stem and dead material and an increase in clover content (Sheath et al. 1987). However, qualitative results of the metabolisable energy (ME) changes in hill country pastures have not been published. In addition there is no information available on the longevity of these effects following uniform defoliation over summer. This trial aimed to determine the effect of different defoliation intensities during spring on herbage quality and composition throughout the subsequent summer-autumn period.

\section{Methods}

In 2011, experimental plots were set up in four climatically distinct hill country farming environments: summer dry (Cheviot, North Canterbury), summer dry/ moist (Poukawa, Hawke's Bay; Woodville, Southern Hawke's Bay/Tararua), summer moist/wet - (Ngaroma, King Country/South Waikato), with a range of average summer (December to February average) rainfall $(150-320 \mathrm{~mm})$ and an average summer (December to February average) soil water deficit (-91 to $-52 \mathrm{~mm}$, calculated with soil water balance equations described by Scotter et al. (1979)). Further site information has been published by Tozer et al. (2013). Plots sized $5 \mathrm{~m} \times$ $5 \mathrm{~m}$, were allocated to treatments on areas of moderate slope $\left(15-25^{\circ}\right)$ without extensive tracking.

The experimental period was separated into two phases; a spring "prevention" phase (September to 


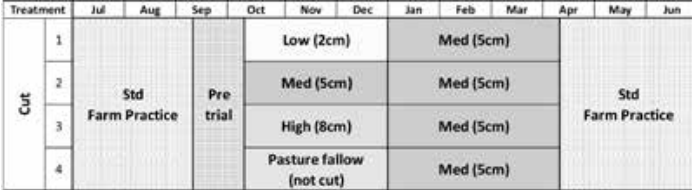

Figure 1 Yearly plan of treatments and plot maintenance

December 2011) and a summer/autumn "maintenance" phase (January to April 2012). The trial contained four spring defoliation treatments (Figure 1) replicated three times on two aspects at each of the four sites. Maintenance phase defoliation was to a common height. Defoliation was achieved with a rotary lawn mower or line trimmer, at 3-weekly (20-25 day) intervals during spring, with summer cutting frequency being climate and growth dependent. Cut pasture was removed from the plot. Fertility removed with pasture was replaced using a fertiliser blend (N:P:K:S:Ca:Mg - 10.4:3.2:20:3.9:7:1.3) to replace the calculated pasture-N removed from each plot. Replacement fertiliser was added following every two to four cutting events, weather dependent, at a rate no greater than 50 $\mathrm{kg} \mathrm{N} /$ ha per application. Pasture quality samples were cut to near ground level prior to cutting plot treatments, dried at $65^{\circ} \mathrm{C}$ for 24 hours, ground and analysed for metabolisable energy content (ME) by feedTECH, Palmerston North, with standard commercial near infrared spectroscopy techniques for pasture quality. In spring 2012 the treatments were reapplied to the same plots without re-randomisation to determine if observed changes in pasture quality were cumulative.

\section{Results}

Summer rainfall and calculated summer soil water deficit are presented in Table 1. The climate data was taken from the NIWA virtual climate station database

Table 1 Summer (December-February) rainfall and modelled summer (December-Febuary) soil water deficit (SSWD) for the trial years and a long term (1973-2014) average from the data of the NIWA virtual climate station database

\begin{tabular}{|c|c|c|c|c|}
\hline \multirow{2}{*}{$\begin{array}{l}\text { Summer rainfall } \\
\text { and modelled } \\
\text { summer soil } \\
\text { water deficit }(\mathrm{mm})\end{array}$} & \multicolumn{4}{|c|}{ Region } \\
\hline & Cheviot & Poukawa & Woodville & Ngaroma \\
\hline Rainfall 2011/12 & 186 & 217 & 292 & 429 \\
\hline Rainfall 2012/13 & 156 & 52 & 233 & 168 \\
\hline 40-y av. rainfall & 163 & 164 & 272 & 323 \\
\hline Std. dev. & 78 & 87 & 102 & 115 \\
\hline sSWD 2011/2012 & -83 & -87 & -43 & -52 \\
\hline sSWD 2012/2013 & -79 & -109 & -97 & -115 \\
\hline 40-y av. sSWD & -73 & -91 & -72 & -52 \\
\hline
\end{tabular}

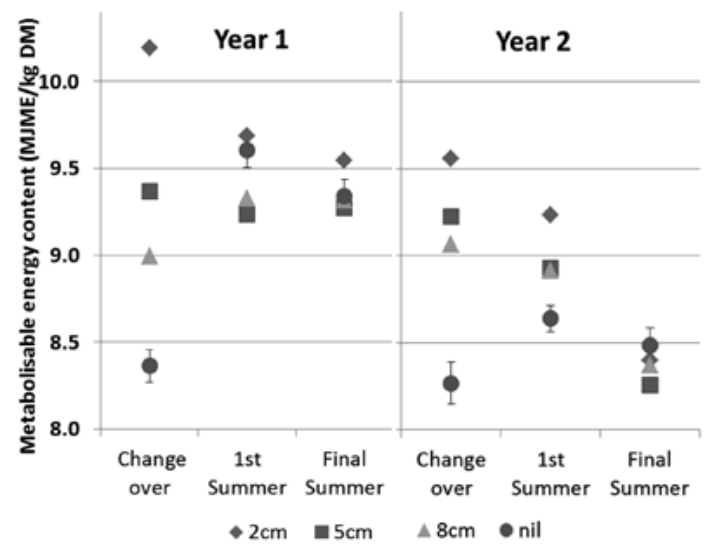

Figure 2 The effect of defoliation height on the metabolisable energy content of pre-cut pasture samples for all sites at the end of spring defoliation treatments (changeover) and following two of the summer regrowth intervals. (Error bars show the 5\% LSD for the treatments).

(Tait et al. 2006) for the 2 years of the trial is compared to the 40-year summer averages for the two presented variables. Year 1 was wetter than average with good pasture growth in most Northern regions. This was in contrast to year 2 where drought conditions occurred in much of the North Island. A similar summer rainfall occurred for both years at Cheviot. The summer soil water deficit was not measured at each region and aspect although the modelled value for region, in Table 1 , gives a generalised value. The northern aspects at each site would be expected to have more severe and more frequent soil moisture deficits over summer than the southern (Lambert 1977).

The ME content of pre-cut pasture samples is shown in Figure 2 at the end of the prevention phase treatment and for two times during the maintenance phase. At treatment changeover (early-December to mid-January, region dependent), the most intense defoliation regime resulted in significantly higher ME than pastures with less intense defoliation. In both years, pasture quality in the $2 \mathrm{~cm}$ treatment was significantly higher, with between a 0.3 to $1.2 \mathrm{MJME}$ advantage over the 5 and 8 $\mathrm{cm}$ treatments.

The difference in summer pasture quality between the treatments reduced under the uniform defoliation regime with large variation in absolute values between seasons. By the time of the final cut during late March to late April (2nd to 4th summer cut depending on regional growth) treatment effects were no longer significant.

The above results are separated into region and aspect in Figure 3. Most region/aspect combinations showed significant differences between treatments at the changeover. In year 1, six of eight site/aspects were 


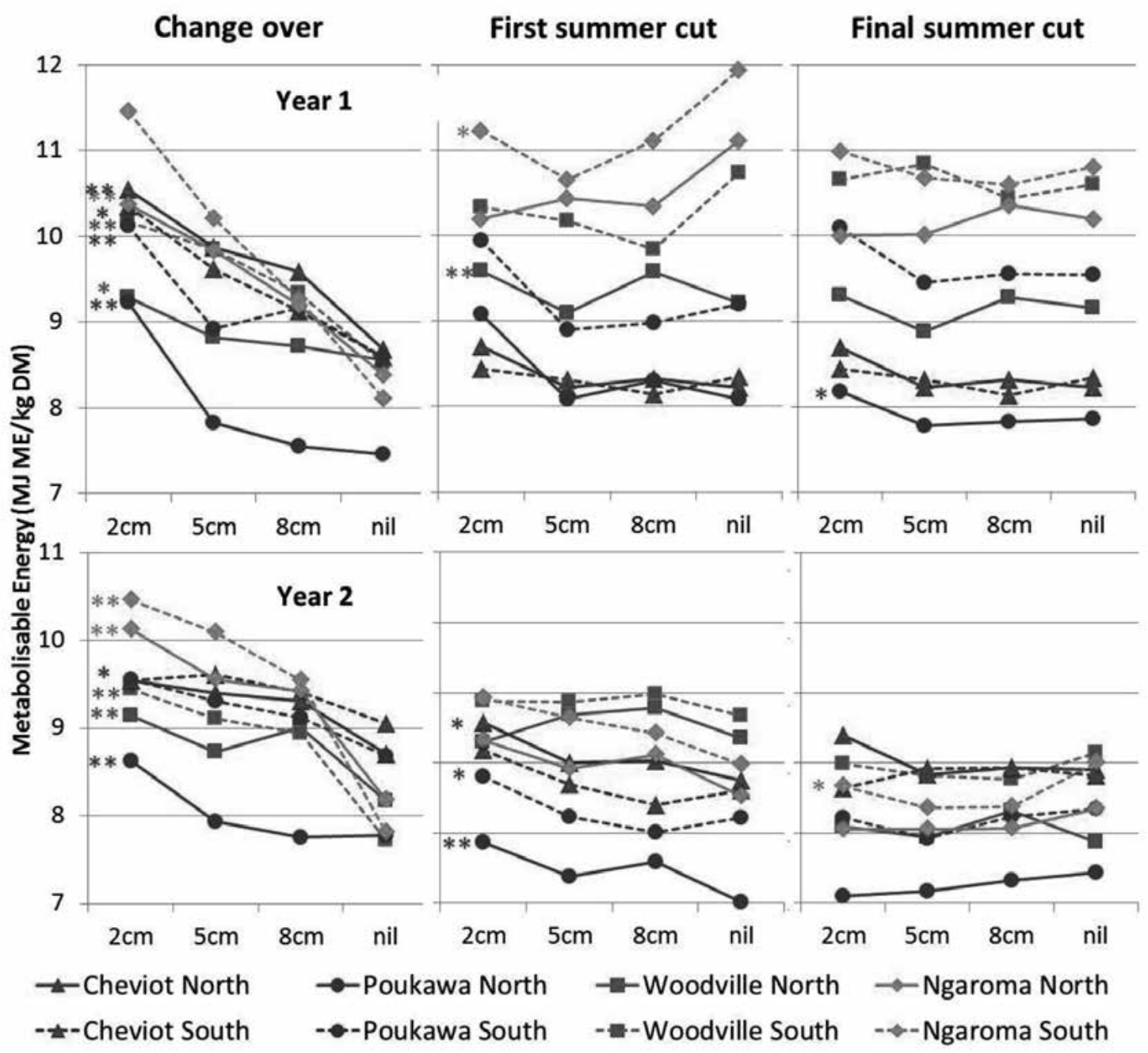

Figure 3 Regional and aspect differences in average metabolisable energy content of pre-cut pasture samples at the change-over (end of spring treatments), following the re-growth from the first summer cut and at the end of the monitoring period at the beginning of April. The significance of treatment effects within each region and aspect is indicated with asterisks; ${ }^{* \star}$ : $\mathrm{P}<0.01,{ }^{*}: \mathrm{P}<0.05$

significantly different at $\mathrm{P} \leq 0.01$ and two at $\mathrm{P} \leq 0.05$. In year 2, five and two sites showed a significant difference at $\mathrm{P}<0.01$ and $\mathrm{P}<0.05$ respectively. Following the first summer cut, few pasture quality differences between the treatments were evident. By the final cut, only one site/aspect in each year showed a probability $(\mathrm{P} \leq 0.05)$ of a treatment effect. It is difficult to extract site specific trends of the effect of defoliation once the data was separated to this level. However, the southern aspects at all sites except Cheviot, are of a higher pasture quality over the summer months than the northern aspects. This correlates with the expected soil moisture availability and previous work reporting a higher pasture quality over summer on more moist southern aspects (Radcliffe et al. 1977).

\section{Discussion}

The defoliation treatments in this experiment were imposed by cutting. This enables idealised defoliation to quantify the potential pasture quality that could be achieved. In a typical hill farming situation grazing is less uniform and controlled. Careful consideration of factors influencing hill pasture utilisation, such as subdivision, stock water and stock intensity would be required for grazing systems to replicate the findings of this experiment.

The defoliation treatments created differences in pasture ME which were at their greatest at the completion of the treatment period in late spring. They followed the expected trend of defoliation to shorter heights resulting in better herbage quality (Binnie \& Chestnutt 
1994; Orr et al. 1988). However, the ME differential began to rapidly equalise following the changeover to uniform defoliation heights. The ME value at which the treatments stabilised could be described as a function of a possible recovery potential of the pasture to the new defoliation regime. It would be difficult for a grazing system to replicate the uniform removal of pasture surplus to a $5 \mathrm{~cm}$ residual in early summer. To continue producing pasture at the developed quality into the summer, soil moisture is required for regrowth.

Weather conditions play a part in maintaining, or reducing, the quality of pasture. The energy content of the pasture over summer was related to regional summer rainfall with higher summer rainfall and available soil moisture generally resulting in higher pasture ME. In Year 1 of the trial, the greater than average summer rainfall resulted in a pasture quality level throughout summer around 1 MJME greater than in year 2. While soil moisture is thought to have a relatively small effect on pasture quality itself (Lambert \& Litherland 2000), the effect of water stress on the regrowth of higher quality portions of the pasture, such as green grass leaf and legumes, could drive the differences observed. Where moisture is available for growth the pasture is able to adapt to the new defoliation height and produce new growth of higher quality.

The variation in pasture quality driven by summer rainfall dwarfed any residual pasture quality effects resulting from the treatments. This indicated that, with idealised defoliation through cutting, the quality of an uncontrolled sward may be recoverable where summer rainfall is adequate for continued growth. This is supported by the results at wetter site/aspect/ season combinations (Year 1, Woodville; south aspect and Ngaroma; both aspects) where the pasture fallow or "deferred grazing" treatment recovered to a higher value than the remaining treatments. Where plant growth and sward recovery is likely to be inhibited due to low soil moisture continued high intensity defoliation into summer may maximise the quality of harvested pasture but would reduce the net herbage accumulation as well as the quantity available at the onset of drought.

Under typical farming practice it may be difficult to replicate this idealised removal of pasture mass through animal grazing in a hill country environment unless sufficient grazing pressure is available.

\section{ACKNOWLEDGEMENTS}

Funding from Ministry of Business, Innovation and Employment, DairyNZ, Fonterra, Beef + Lamb New Zealand and DCANZ; advice on farmer needs from Beef + Lamb New Zealand; farmers hosting and assisting with trials; AgResearch and On-Farm Research staff for undertaking the trials.

\section{REFERENCES}

Binnie, R.C.; Chestnutt, D.M.B. 1994. Effect of continuous stocking by sheep at four sward heights on herbage mass, herbage quality and tissue turnover on grass/clover and nitrogen-fertilized grass swards. Grass and Forage Science 49: 192-202.

Clark, D.A. 1994. Grazing for pasture management in New Zealand. In: Pasture management tecnology for the 21 st century. Eds. Kemp, D. R.; Michalk, D. L. CSIRO Australia.

Lambert, M.G. 1977. The influence of aspect on pasture environment. Proceedings of the New Zealand Grassland Association 38: 78-86.

Lambert, M.G.; Litherland, A.J. 2000. A practitioner's guide to pasture quality. Proceedings of the New Zealand Grassland Association 62: 111-115.

Orr, R.J.; Parsons, A.J.; Treacher, T.T.; Penning, P.D. 1988. Seasonal patterns of grass production under cutting or continuous stock managements. Grass and Forage Science 43: 199-207.

Radcliffe, J.E.; Young, S.R.; Clarke, D.G. 1977. Effects of sunny and shady aspects on pasture yield, digestibility and sheep performance in Canterbury. Proceedings of the New Zealand Grasslands Association 38: 66-77.

Scotter, D.R.; Clothier, B.E.; Turner, M.A. 1979. The soil water balance of fragiaqualf and its effect on pasture growth in central New Zealand. Australian Journal of Soil Research 17: 455-465.

Sheath, G.W.; Bircham, J.S. 1983. Grazing management in hill country: pasture production. pp. 41-45. In: Proceedings, Ruakura Farmers' Conference, 1983. Hamilton.

Sheath, G.W.; Boom, R.C. 1985. Effects of NovemberApril grazing pressure on hill country pastures. 1. Pasture structure and net accumulation. New Zealand Journal of Experimental Agriculture 13: 317-327.

Sheath, G.W.; Hay, R.J.M.; Giles, K.H. 1987. Managing pastures for grazing animals. pp. 65-74. In: Livestock feeding on pasture. Ed. Nicol, A. M. New Zealand Society of Animal Production, Hamilton.

Smeaton, D.C.; Wadams, T.K.; Mackisack, B.D.; Winter, R.D.; Miller, C.M.; Hockey, H.-U.P. 1984. Spring-summer grazing management on hill country: effects on ewe performance. Proceedings of the New Zealand Society of Animal Production 44: 117-120.

Smith, M.E.; Dawson, A.D. 1977. Hill country grazing management. Proceedings of the New Zealand Grassland Association 38: 47-55.

Tozer, K.N.; Douglas, G.B.; Cameron, C.A.; Fraser, T.J.; Moss, R.A.; Rennie, G.M.; Knight, T.L.; Muir, P.D. 2013. Pasture establishment on non-cultivable hill country. Proceedings of the New Zealand Grassland Association 75: 215-220. 